\title{
The Influence of Covid-19 Pandemic on Emprak Art in Jepara
}

\author{
Alamsyah $^{1 *} ;$ Siti Maziyah ${ }^{1}$ \\ ${ }^{1}$ Lecture of Department History, Faculty of Humanities, Diponegoro University, Semarang \\ - Indonesia
}

\begin{abstract}
Abstrak. This article was to explain how the Covid-19 pandemic that occurred in Indonesia from the beginning of 2020 to 2021 had an effect on Empark Art existence in Jepara. The purpose of the study was to describe analytically the impact of covid on the emprak art existence and how to make emprak art in Jepara sustainable. The method used was a descriptive qualitative and historical method. The results showed that the Covid-19 pandemic had reduced the Emprak art performance. This decline affected the artists' creativity and economic income. On the creativity side, they rarely practice because there were no performances. This condition hampered the regeneration process. The artists, especially the younger generation, were more focused on activities outside the arts. From the economic side, the artist's income had also decreased, and even there was no income anymore. On the other hand, the regulations of staging prohibition to prevent the spread of COVID-19 had made emprak art even worse. This was what made this art suspended. Therefore, there needs to be an effort from the artists, government, and the supporting community so that this art can survive and be sustainable. The conclusion showed that the Covid-19 pandemic had an effect on the emprak existence related to the artists' income and regeneration process.
\end{abstract}

\section{Introduction}

In Indonesia, two cases of Coronavirus (2019-nCoV, or COVID-19) were first reported on 2 March 2020 [1]. The existence of the Covid-19 pandemic in Indonesia affects various aspects of life, including the tourism and arts sectors [1]. The government has issued a policy of social distancing and limiting crowds. The existence of this policy has an impact on the arts industry. Performing arts (theatre, dance, music) demands synergy in four main areas; they are time, space, artists, and the relationship between the artist and the audience. This government policy is certainly burdensome for artists to carry out their activities. Based on the existing data shows that around 40,081 artists have been affected by the Covid-19 pandemic due to the cancellation of art performances and festivals. These artists come from West Java, DKI Jakarta, East Java, Yogyakarta and Central Java [2]. The performing arts industry is experiencing shocks due to the Covid-19 pandemic.

\footnotetext{
* Corresponding author: alamsyah.fib@live.undip.ac.id
} 
At the local level, COVID-19 also affects various sectors. One of the things that affected is the activity of performing arts in public spaces. This sector is prone to crowds, so that the art performances have been stopped. This condition is experienced by emprak art in Jepara. During this pandemic, the Jepara government issued a policy to ban crowd activities [3]. Some efforts made are by issuing restriction rules. As a result, some arts that are almost extinct are increasingly having difficulty surviving in the creative industry, including emprak [4].

Emprak art from Jepara is one of the arts that is almost extinct, so it needs to be preserved. Emprak is a folk art that lives in the locus of coastal culture [5]. This art is generally performed as a means of expressing gratitude to God Almighty [6]. Emprak had experienced its heyday at the end of the 20th century but began to decline at the beginning of the 21 st century. In this period, emprak could not compete with modern art, even though it had withstood various challenges.

From 2020 to 2021, the art of emprak had never performed. This was in line with the Jepara Regent circular letters for 2020 and 2021 regarding the imposition of restrictions on micro-based community activities at the village and sub-district levels to control the outbreak spread. In 2020, a temporary suspension policy was issued for socio-cultural activities, including art performances deemed to cause crowds. In 2021, a circular letter regarding the extension of the imposition of restrictions on community activities at the village and sub-district levels was also issued. This policy was related to the regulation of the imposition of restrictions on public facility activities and socio-cultural activities that could cause crowds [7]. This policy made Emprak Art unable to perform. When the performance is carried out, it will certainly cause the crowd and community movement. This affects the creativity, regeneration process, and economic income of emprak artists. On that basis, this article explains the existence of the Covid-19 pandemic and its influence on emprak art in Jepara.

\section{Method}

The research, which was located in Jepara, aims to observe the phenomenon of Emprak art in the midst of the Covid-19 pandemic and its influence on this art existence. This research used descriptive qualitative data. The data was in the form of written or spoken words from people related to the object of research [8]. Emprak Jepara art was the main object of research. In addition, this study also used a historical method which consisted of several stages [9]. First, heuristics, which was the process of searching, collecting, and finding sources, both primary and secondary, related to writing. Primary sources were obtained from interviews with emprak art artists. Meanwhile, the secondary sources were obtained from books, articles in journals, both online and printed, and etc. The second stage was criticism to obtain authentic and credible data. Good data is data that is collaborated with other data in order to obtain a comparison [10]. The third stage was to interpret various data obtained in order to obtain an integral understanding related to the existing facts. The last stage was historiography, or the compiling data process into systematic writing so that it can be understood and becomes an article about the influence of the Covid-19 pandemic on emprak art in Jepara. 


\section{Discussion}

\subsection{History of Emprak}

There are several versions of emprak art in Jepara. The first version states that the birth of art began when farmers were enjoying the harvest, and this performance was a gratitude expression to God Almighty. They had a party together by performing dance and music. The farmers used simple musical instruments, such as gamelan and bamboo, that were split at the ends. If the split bamboo is beaten, it will produce prak-prak sound. The sound of split bamboo music and produces the prak-prak sound is known as emprak [11]. Another opinion stated that emprak art is believed to be an art that has existed since Wali Songo era, which is estimated to be around the 15th century [12].

From another version, based on the oral story that developed in Jepara, the art of emprak was born around the 16th century. At that time, there was an art troupe consisting of six people. They travelled from one village to another, performing art to the community. In their performance, they used musical instruments in the form of a large drum and a small drum. While performing, they met two Arabs. The two Arabs brought a big tambourine and a small tambourine. The local artists and the two Arabs decided to collaborate to work together as a group. They started to form an art group. This art complimented their musical instruments with goprak, which is an instrument made of bamboo which is split or broken at the ends part of bamboo; when it is hit, it has "prak-prak" sounds. During its development, this musical instrument has experienced changes and modifications to date

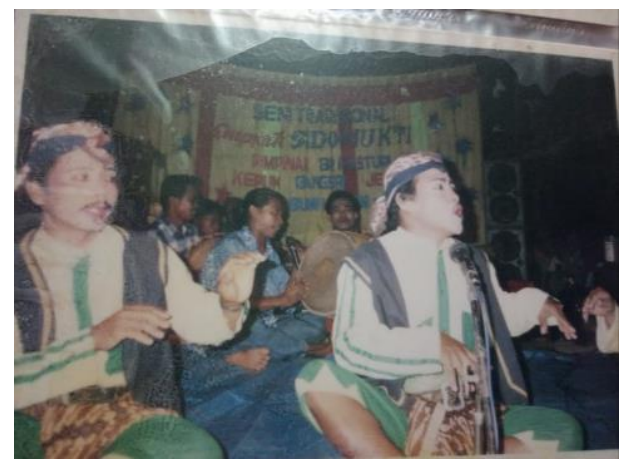

Fig. 1. Emprak players are doing performance. Source: Author's personal collection, 2020

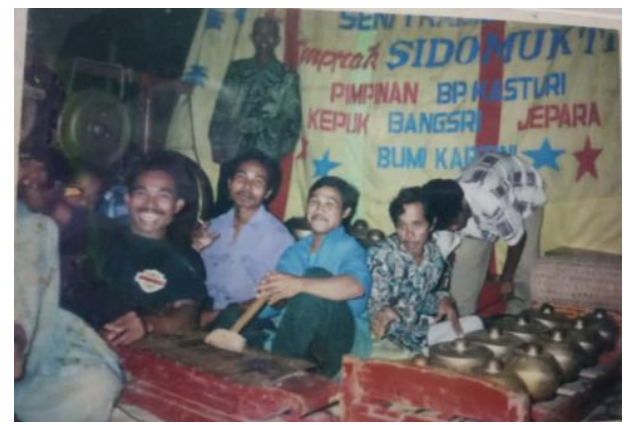

Fig. 2. Emprak musical instrument players.

Source: Author's personal collection, 2020 
Based on the existing history of this art, it shows that emprak is not only an artistic performance but is basically related to spiritual values. The art that is located in Bangsri sub-district, Jepara experiences development continuously. The association of this art with sacred rituals can be traced back to the 1960s. At that time, emprak began to be called a ritual art because its performances were always related to sacred events and had a close relationship with the rites of human life. In the 1980s, Emprak art experienced a shift because it was not only used as entertainment but was also used by the New Order government as a formation media and a political legitimacy tool [14].

In the 1980s to 1990s, Emprak was the prima donna art for the Jepara people. Emprak had become the entertainment eagerly awaited by the community in every celebration event [15]. In the early 2000s, Emprak experienced a setback because it could not compete with dangdut performances. The community prefered to invite dangdut shows because it was cheaper in terms of the costs than the cost of Emprak performance [16]. In 2011, in Jepara there were only two Emprak art groups, they were Emprak Sido Mukti art group in Kepuk Village, Bangsri District and Emprak Sido Lancar art group in Plajan Village, Pakis Aji District [17]. Until now, emprak has experienced a decline, but there are some people who still ask the artist to perform at a community celebration event. The emprak decline was exacerbated by the 2019 Covid pandemic, which limited or even banned staging because it created a crowd. This certainly affected the emprak existence in Jepara.

\subsection{The Influence of Pandemic on Regeneration and Creativity}

The central and regional governments carried out various policies in an effort to prevent the Covid-19 transmission. The government imposed restrictions and prohibitions that could trigger crowds [18]. The Jepara regional government had also implemented various regulations to prevent the spread of Covid-19. On March 16, 2020, Jepara Regent issued Circulars No. 440/1313 the Year 2020, which postponed and or limited activities that brought large crowds in public places. Jepara Government had also suspended permits for community crowds [19]. The Jepara government strengthened the restriction rules by issuing Regent Regulation no. 52 of 2020, which generally regulated restrictions on community activities, including restrictions on social and cultural activities. In 2021, the imposition of restrictions on community activities related to public facility activities and socio-cultural activities could cause crowds, including emprak art [20].

Emprak performance, which involved many people, like the players and audience, was greatly affected by the limitation policy during this pandemic. Even though the local government actually still allows Emprak art performances with a long licensing process, and must meet several conditions. Among them, art organizers must have coordination in licensing with the Regional Government, the Regional Covid-19 Handling Task Force, Police, Health Service, Regional Hospital, Fire Service, and the Regional Disaster Management Agency. The organizers must also meet the requirements of health facilities and equipment such as temperature measuring devices, hand washing stations, medical rooms, ambulances, and fire extinguishers [21]. These conditions were quite hard, making people hesitated to invite emprak to perform. This requirement had given effect because emprak art had never been invited from 2020 to June 2021 [22].

When this art did not perform, the emprak players also never practice. This condition affected the creativity of the artists. They were more focused on meeting their economic needs from other sectors rather than doing art practices. The emprak performers were getting difficulties developing their creativity because creativity emerges from the practising and performance process. On the other side, the absence of the performances made the performers of Emprak Jepara experience problems with regenerating artists. The apprenticing process of new performers could not be done during this pandemic [23]. 
Before the pandemic, the Emprak artists had been looking for talented young people who were trained to become emprak performers. Because of the pandemic, the regeneration activities of new performers had stopped. Emprak performers cancelled the plans to recruit new members because there were no performances in the past year. No staging means no practice. Seeing this condition, the artists were pessimistic about the regeneration process and Emprak development [24]. They were more focused on outside activities so that the emprak art future and existence was increasingly bleak. On the other hand, the regeneration process is very important so that this art can compete with other modern arts and cultures. If emprak still rely on the old performers, they will be stagnant and will be shunned by the audience [25].

The existence of emprak art, which experienced a decline during the pandemic, had an effect on the regeneration process and its existence. In fact, during this pandemic, Jepara regional government had tried to encourage the arts to keep existing during the pandemic. The government encourage artists to perform virtually or online [26]. However, when no one is responding, the virtual stage cannot be performed either. However, when no one asking the emprak art to perform, the virtual stage could not be held either. Another obstacle was that most Emprak artists were old generation, so they were less familiar with the technology.

\subsection{The Influence of Pandemic on the Artists' Economy}

Various economic sectors in Indonesia have been affected by this pandemic. The community groups who were most vulnerable to the economic downturn were those with daily income [27]. Arts Performer is a profession with daily income, so they can be categorized as the vulnerable group. Arts performers earn income when they do performances; if there is no stage, they will not get income. The arts performers were affected by the pandemic. It is because the art performers get some cancellation of their art performances and festivals. Those who lost their jobs mainly came from West Java, Jakarta, Central Java, East Java and Yogyakarta [28]. Emprak artists in Jepara also got economic impacts during the pandemic. They had not performed on stage for more than one year, that was from 2020 to June 2021 [29]. As a result, the artist did not get income.

This condition was strengthened by the Jepara Regional Government policy, which was issued concerning crowd restrictions. When this art has a performance, it will surely create a crowd audience. If the art performance got its permission, many procedures must be filled so that the organizer can cancel the performance. When they do not perform, the players do not get income or their income decreases. When art performers do not make the artistic activities their main economic source, then they will not get the effect when there is no performance. However, for artists who depend their life on artistic activities, the effect will be felt [30].

As an illustration, to capture the income of emprak artists before the pandemic, an artist usually performs two to three times a month. During one year, they could perform about 24 to 36 times. Each artist received about Rp. 200,000, - for one stage. Thus they got an income of Rp. 600,000, - every month. For one year's income, it was around Rp. 7,200,000, -. For the artists who did not depend their livelihoods on Emprak performance, they could still fulfil their family necessities [31].

During this pandemic, artists never performed again, so they didn't get any income. This condition made the art performers felt devastated. According to them, the pandemic had reduced their economic income. Furthermore, the price of daily necessities had remained the same or even increased [32]. This was what made the artists affected economically. Efforts made by the government in assisting art performers have been carried 
out by the Directorate General of Culture, Ministry of Education and Culture [33]. However, the benefits of this program had not been felt for the performer of the Jepara emprak art. The Jepara local government has also tried to help by easing the licensing process for performing arts, but in reality, there are still no performances [34]. The community is still unwilling to invite Emprak art to a celebration and other activities.

\section{Conclusion}

The Covid-19 pandemic had a considerable influence on emprak art in Jepara. Even though this art is one of the typical arts of Jepara that needs to be preserved. When a pandemic occurs, the existence of this art is increasingly threatened. Even though it was long before the pandemic, emprak art activity had decreased. When a pandemic occurs, there are bans and restrictions on crowd-rising activities. This condition affects creativity and regeneration because there is no performance or practice. Emprak artists are also affected economically because there are no performances. For emprak artists, the income from the stage is expected able to support their family life. Efforts of the central and local governments to assist the arts, including emprak art, is through regulations, and the assistance has not been felt by art performers. Therefore, serious efforts are needed so that this art can be preserved even in the midst of pandemic and post-pandemic.

The research is funded by Institute For Research And Community Services (LPPM) Diponegoro University in 2021 budget year.

\section{References}

1. E. D. Sihaloho, The Impact of Covid-19 on the Indonesian Economy, (2020)

2. L. Safriana, (2020), Heavy Challenges for Performing Artists during the Corona Pandemic, Retrieved from https://katadata.co.id/opini/2020/04/18/tantangan-beratseniman-pertunjukan-di-masa-pandemi-corona

3. (2020), Prioritize Community Safety, Plt Regent Will Issue Circular Letter, Retrieved from jepara.go.id

4. Ministry of Education and Culture, The Impact of Covid-19 Pandemic on Artists and Creative Industry People, (2020)

5. B. Wrahatnala, I. Kurniatun, B. A. Manggala, Dissemination of Audio Visual as a Model for the Development of Emprak Folk Performing Arts in Plajan Village, Pakis Aji District, Jepara Regency, (2020)

6. K. Anggoro, Emprak Sido Mukti Traditional Arts, Kepuk Village, Bangsri District, Jepara Regency, (2013)

7. Jepara Regent Regulation No. 52 year 2020 Regarding The Restrictions on Community Activities and Implementation of Health Protocol Disciplines to Prevent the Spread of Corona Virus Disease 2019, (2021); Jepara Regent Circular Nomor 443/ 1940 Regarding the Extension of Limitation on Micro-Based Community Activities and Optimizing the Corona Virus Disease 2019Management Post at the Village and SubDistrict Level for Controlling the Spread of Corona Virus Disease 2019 in Jepara Regency, (2021)

8. A. Prastowo, Qualitative Research Methods In Perspective, (2012)

9. L. Gottschalk, Understanding History, (1975) 
10. L. Gottschalk, Understanding History, (1975)

11. K. Anggoro, Emprak Sido Mukti Traditional Arts, Kepuk Village, Bangsri District, Jepara Regency, (2013)

12. D. W. Saputra, The Existence of Emprak Performing Arts in Kaliopak Islamic Boarding School, (2015)

13. D. W. Saputra, The Existence of Emprak Performing Arts in Kaliopak Islamic Boarding School, (2015)

14. B. Wrahatnala, I. Kurniatun, B. A. Manggala, Development of the Emprak Performing Arts in Jepara Regency through the Making of Feature Documentaries, (2014)

15. Inibaru, (2019), Emprak, Jepara's Typical Art which is Full of jokes, Retrieved from https://www.inibaru.id/tradisinesia/emprak-kesenian-khas-jepara-yang-sarat-lawak

16. Wawancara Bapak Sugiri, Emprak art performer Jepara, 9 November 2020

17. B. Wrahatnala, I. Kurniatun, B. A. Manggala, Development of the Emprak Performing Arts in Jepara Regency through the Making of Documentary Features, (2014)

18. Kementerian Dalam Negeri, General Guidelines for Facing the Covid-19 Pandemic for Local Governments, (2020)

19. Circular Letter of the Regent of Jepara No. 440/1313 Tahun 2020 Concerning Increased Alertness Against the Risk of Corona Virus Disease (Covid-19) Infection in Jepara Regency

20. Regulation of Jepara Regent No. 52 Tahun 2020 Regarding Restrictions on Community Activities and Implementation of Health Protocol Disciplines to Prevent the Spread of Corona Virus Disease 2019

21. Kreatif, Kementerian Pariwisata dan Ekonomi., Implementation Guidelines of Cleanliness, Health, Safety and Environmental Sustainability in Organizing Activities (Event), (2020)

22. Wawancara Bapak Sugiri, Emprak art performer Jepara, 9 November 2020

23. Wawancara Bapak Sugiri, Emprak art performer Jepara, 9 November 2020

24. Wawancara Bapak Sugiri, Emprak art performer Jepara, 9 November 2020

25. Wawancara Bapak Sugiri, Emprak art performer Jepara, 9 November 2020

26. Sulistiyono, (2020), Cultural Arts Must Rise in the Middle of a Pandemic, Retrieved from https://jepara.go.id/2020/11/13/kesenian-budaya-harus-bangkit-di-tengahpandemi/

27. F. R. Yamali, R. N. Putri, The Impact of Covid-19 on the Indonesian Economy, Ekonomis: Journal of Economics and Business, 4(2), (2020)

28. D. F. Anisa, (2020), As many as 40,081 Artists Affected by the Negative Impact of Covid-19, Retrieved from https://www.beritasatu.com/hiburan/617987/sebanyak-40081seniman-terkena-dampak-negatif-covid19

29. Wawancara Bapak Sugiri, Emprak art performer Jepara, 9 November 2020

30. Wawancara Bapak Sugiri, Emprak art performer Jepara, 11 Mei 2021

31. Wawancara Bapak Sugiri, Emprak art performer Jepara, 9 November 2020

32. Sihaloho, Estro Dariatno., The Impact of Covid-19 on the Indonesian Economy,(2020)

33. S. Oebadillah, (2020), The Impact of Covid -19, Thousands Art Workers Will Get Social Assistance, Retrieved from https://mediaindonesia.com/humaniora/302348/dampakcovid-19ribuan-pekerja-seni-akan-dapat-bansos 
34. A. Muharror, (2020), This is the promise of the Jepara Regency Government to Thousands of Art Workers, Retrieved from https:/www.gatra.com/detail/news/490235/info-pemda/ini-janji-pemkab-jepara-kepadaribuan-pekerja-seni 